\title{
Teaching Catholic Religious Education and Islamic Studies in a monopoly Catholic small state
}

\author{
Mary Darmanin
}

\section{Introduction}

Professor Gerald Grace has helpfully provoked important debates regarding faith-based education and schooling (Grace, 2003), as well as outlining research agendas for Catholic education in particular, and religious cultures more generally (Grace, 2004, 2009, 2020). Other contributors to this volume will take up themes from Grace's vast repertoire of insights. Here, I wish to honour Gerald's 'provocations' by looking at the sustainability of Catholic Religious Education as well as Islamic Studies curricula in denominational schools in Malta. Gerald is deeply concerned about the future of religious cultures in a world of 'secular marginalisation' (Grace, 2003, p. 149). He wishes to see research about 'challenges to the faith, moral and social formation of youth and adults' (Grace \& Valenti, 2009, p. 2). One such challenge lies in asking how far the Religious Education (RE) curriculum invites young learners to engage with faith from a life-centred approach, without jeopardising a sound knowledge base. For a number of years now, Grace (2004, p. 51) has also encouraged research that incorporates accounts of 'the educational institutions and cultures of Islam'; sociologists of education are called upon to 'deepen their understanding of the cultures of Islam' (Grace, 2020, p. 867).

This chapter takes up Grace's (2003, 2004, 2009, 2020) appeals by examining how the Catholic RE and the Islamic Studies curriculum are seen by teachers to engage young learners such that Catholic RE and/or Islamic Studies curricula and pedagogies fruitfully contribute to sustaining religious cultures.

This chapter reports on data generated from an EU-funded project [REMC] ${ }^{1}$ on the place of religion in educational systems across Europe, specifically on the religious education of primary school children in Malta, the EU's smallest member state. Malta is a confessional state, where the Roman Catholic Church has held a monopoly over RE for centuries (Zammit Mangion, 1992). Having had small, non-Catholic populations in the past, membership of the European Union in 2004, and the recent immigration from North Africa are presenting a more religiously plural group of pupils in school than the monoculture has prepared for (Eurydice, 2004). There has, to date, never been any RE alternative 
to the Roman Catholic doctrinal, knowledge-centred, and outcomes-based curriculum. Malta has no history of a 'world religions' or multi/intercultural-type interpretive RE (Jackson, 2004), nor of a more hermeneutical or interpretivebased Christian one (Dillen, 2007a). In the early 1990s, some curricular reform was undertaken, which led to an 'upgrading' of textbooks, which, as Vella (1992) notes, paid more attention to children's cognitive development than to experiential learning. Some elements of a life-centred approach were also introduced. As the field research reported here demonstrates, many teachers and children felt that this was not a sufficient balance to the rigidities of the doctrinal knowledge-centred outcomes-based approach (Buchanan and Engebretson, 2009). Although centrally prescribed, confessional RE has, over time, been implemented differently across the State, government-dependent Church, and independent school sectors. Teachers' translations of the policy directives as they interacted with the RE curriculum demonstrate how the centrally prescribed syllabi were experienced as limiting; it raises questions regarding the purpose and future of Catholic RE. In contrast, teachers of Islamic Studies were more content with the Islamic Studies curriculum, finding it consonant with their preferred pedagogic modes, as well as their faith and values.

\section{The Maltese RE settlement}

The Maltese RE settlement neither protects the human rights of minority-religion pupils through an intercultural RE (Mawhinney, 2007), nor does it operate a system of 'voluntary apartheid' (Halstead, 2005) where minority-faith schools are State funded. ${ }^{2}$ In 2008, when fieldwork was undertaken, its denominational State and Church schools did not aspire to be relevant to a more plural society (MacMullen, 2004). Pedagogically, there was no contrast of arguments between diverse faiths, nor were pupils introduced to other faiths or ethical systems as themselves of value (Vermeer, 2010). At the organisational level, it was only the Muslim school which employed non-Muslim (Christian) teachers, whilst the government-dependent Church schools were the most closed, restricting both appointment of teachers and admission of pupils to those of the one faith. There was and is no awareness within the Catholic RE policy community of the cultural-normative integration that even denominational schools may provide (Vermeer, 2010). Notwithstanding, there is some space for ethical autonomy (MacMullen, 2004), cultural attachment (Halstead, 1995) and the development of some hermeneutical (Dillen, 2007a and 2007b) or interpretive skills, these stop considerably short of the critical 'edification' that Vermeer (2010, p. 112), following Jackson (2002), espouses. In contrasting the RE experience of the more curriculum-conforming State school teachers and pupils with those of the innovative life-centred Church schools, and the rather 'fluid' method of the independent school, it is possible to see what different approaches bring to children's RE. The Islamic Studies of the Muslim independent school, which blends a knowledge-centred outcomes-based approach with a hermeneutic 
spiritual approach, provides a further contrast. It reminds us what Muslim pupils in State schools miss, when their only option is to opt out from Catholic RE, or into Ethics Education (provided since 2012 and slowly being rolled out in all schools), which, despite their supposed constitutional right to a religion, leaves them without a religious education; a problem not addressed by education planners at all.

Given the constitutional entrenchment of Roman Catholicism as the religion of Malta, the mandatory provision of (only) Roman Catholic RE in all State schools, and of agreements with the Holy See and the Episcopal Conference on religious instruction, the RE settlement in Malta can be described as one of monopoly Catholicism, currently becoming more secular with the 2013 introduction of an Ethics Education programme as an opt out of Catholic RE. Within this settlement, the Constitution protects freedom of conscience and of worship through clauses permitting the 'opt out' of Catholic RE. In 1991, $0.08 \%$ children opted out of confessional RE in State schools (Vella, 1992), rising to $0.02 \%$ in $2009 .{ }^{3}$ With the gradual phasing in of the Ethics Education programme, $8.2 \%$ of primary and $12.9 \%$ of secondary State school children have opted of Catholic RE (hereafter RE). In the independent school sector, $54.8 \%$ opt out of Catholic RE (Debono, 2019).

\section{Religious Education and Islamic Studies curricula}

In the State school sector, the Maltese Episcopal Conference 'establishes the teaching methods, programmes and texts for students, whilst responsibility for implementing the curriculum policy rests with the State Directorate of Quality and Standards in Education (DQSE)' (Secretariat for Catechesis, 2008, p. 22). The Episcopal Conference also regulates teacher appointments in Religious Education and Religious Counselling. The settlements reached between the State and the Holy See and the Episcopal Conference bind all schools with Catholic pupils to a prescribed RE programme. Government-dependent Church schools and independent schools have more curricular freedom than do State schools. One Church school, had, in the year of study, introduced an innovative 'pilot' curriculum 'powered by Christ'; it was awaiting approval from the Secretariat for Catechesis for this. An Islamic Studies education is available in two independent Muslim schools. Halsall and Roebben (2008, p. 20) categorise Malta's approach to Religious Education as a 'denominational RE system for all' within a 'uniform solution with strong state intervention'; this in contrast to the 'pluriform or mixed solution with weak state intervention' of a number of other EU member states. Despite the uniformity, this study demonstrates that schools in different sectors have some autonomy in transposing curricular directives.

As recently as 2010, in the State sector, RE was one of five examinable subjects in Year 5 of primary school, which allocated children to different streams. At $11+$ it allocated them to different secondary schools in a selective system. Since a 'reform' of the selective system in 2010, RE no longer contributes to the 
allocation of pupils to different schools. However, along with other subjects, until a few years ago, 'benchmark tests' in RE allocated pupils to sets (tracks) within State secondary schools.

In June 2008, the Secretariat for Catechesis, Archdiocese of Malta (Secretariat for Catechesis, 2008, p. 24) published a working document on RE in Malta, courageously noting a number of challenges, amongst which are the datedness of the syllabi and texts in circulation (over twenty years old), emphasising an 'imbalance' in favour of the cognitive domain, rather than the affective. A number of concerns regarding the curriculum for the primary school were raised: that the curriculum neglected spiritual education; the language of the set texts was no longer comprehensible; the material was 'scant'; and that the present generation was 'less acquainted with religious stories' such that they may have been unable to engage with those presented in the syllabi and set textbooks. Additionally, an overlap between RE in schools and Catechesis in the parish was seen to pose further challenges. The religious education of children of minority or no faith in Maltese schools was nowhere addressed in this document, where an assimilationist perspective is assumed. A number of new curriculum initiatives were underway. Though the final report (Secretariat for Catechesis, 2008) was concluded after consultation with stakeholders, the planning for the new initiatives suffered from not incorporating the viewpoints of children, their parents and their teachers.

As a statement of curricular objectives rather than a syllabus, the National Minimum Curriculum (Ministry of Education, 1999) paid lip service to multiculturalism (Borg and Mayo, 2001) at the same time as it entrenched Roman Catholicism as the religion worth teaching and learning, arguing that, through it, other values could be accessed: 'knowledge of Religion is in itself essential for the moral and spiritual development of a society around values that lie at the heart of social conviviality and understanding' (Ministry of Education, 1999, p. 48 passim). The knowledge/information that students were expected to acquire through the curricular experience include learning about 'their rights and responsibilities in relation to the Creator (for those who believe ${ }^{4}$ ), to others, themselves, the community, the country, the natural environment and animals' (Ministry of Education, 1999, p. 48).

In terms of skills, it was expected that students would develop the ability to 'search for the religious dimension in the realities and experiences of life; find time to discover and grow spiritually; develop means through which they become conscious of the power of the Spirit especially in times of great difficulty; participate actively and meaningfully in religious celebrations' (Ministry of Education, 1999, p. 53). Amongst attitudes, desired outcomes included to 'trust in and [have] contact with God', to have 'appreciation of Jesus Christ as the Way, the Truth and the Life' and 'courage through the power of the Spirit'. Students should also have 'respect for others who profess a different religion or choose not to profess any' (Ministry of Education, 1999, p. 54). 
Detailed prescriptive syllabi were and are issued by the Department of Curriculum Management, now within the Directorate for Quality and Standards in Education (DQSE). They are posted on the Department's website. Level descriptors were developed, but as the Working Document (Secretariat for Catechesis, 2008, p. 24) argues, both the syllabi and the level descriptors 'are not written in comprehensible education language'. All the documents were in the Maltese language, which is the language of instruction for this subject in State schools. Most of the textbooks, teachers' guides and work-books were also in Maltese, though some English language material was available; they are used in those Church and Independent schools where English is the language of instruction.

In the Muslim independent school (MIS), the curriculum is planned by the Imam, together with the Islamic Education/Arabic teachers, who follow standard universal Islamic Studies (hereafter IS). A Libyan textbook has been adopted for Islamic Studies whilst a French one is used for Arabic. In Libya, children enter primary school at age 6 whilst in Malta entry is at age 5. The problem of cognitive difficulty is aggravated because the pupils are not Arabic first-language speakers. The teachers of IS would have liked to be more involved in curriculum planning. The course was designed over seven sessions a week, of which five are usually Islamic Studies and two Arabic language, but with considerable overlap. Sura are discussed for meaning, but then memorised and recited.

\section{Methodology}

Primary data was collected on the relative roles of school and home in the religious socialisation of primary school children, age 9-11, some of which is reported here, but see Smyth et al. (2013) for a fuller account. This chapter is based on in-depth interviews with seven Catholic RE and two IS teachers in five schools in the State, government-dependent Church and Independent sectors in Malta. Observation of lessons and other school-based activities was also carried out. ${ }^{5}$ Ethics approval from the University of Malta's Research Ethics Committee was obtained. Recruitment of all participants was on an 'opt-in' basis.

\section{Teachers' accounts of teaching Catholic RE and Islamic Studies}

Teachers from the different education system sectors expressed quite distinct attitudes to the curriculum in use in their respective schools. State school teachers were most constrained by the national curriculum and by the demands of a syllabus closely geared to the end-of-cycle 11+ examinations. Interestingly, the case-study Church school had rejected this curriculum, in favour of its own curriculum, despite the official curriculum being the one developed and approved by the Episcopal Conference. The teachers of Catholic RE in an independent school were nearly ignorant of the official RE syllabus; they 
followed an English language textbook, which, however, left them with less support for teaching RE than they wished. The teachers of Islamic Studies in the Muslim faith school did not articulate any difficulties with the format of the Islamic Studies curriculum, nor with its pedagogic mode, suggesting there is coherence in this curriculum.

\section{State school teachers}

Patri Said and Vassalli State schools both followed the centrally prescribed curriculum and textbooks the most closely of all the five schools studied. However, there were some differences between the two schools. In both schools, the regular primary school class teacher is also the RE teacher; each teacher was unhappy about this. RE was one of the examinable subjects at $11+$ at the time. Many children from both schools failed this RE exam and this lowered their overall performance. At Vassalli, one teacher argued for a life-centred approach; ironically, he had, at the same time, published a 'crammer' preparing the Year 6 pupils for the 11+. The other teacher approved of the structure and discipline imposed by the text, which as his comment illustrates, did combine elements of both knowledge and lifecentred approaches to RE.

Mr John: If I could, I would change the Religion syllabus. And I would get rid of the examination too. I wouldn't examine at all. Because Religion is not something you teach for faith. It is good to learn things, but religion is something you need to live. And it is this that we should be teaching. To live it. Now if I teach the children, say, the prayer blessings. They can say it [sic] by heart [recite it from memory]. They can recite the Creed. But then what is religion, to live the religion [here used as substitute for 'faith']? If one is going to kick someone without feeling bad, without understanding "I am going to hurt that [other] child" it is useless to know the Creed by heart. So I would make him do something concrete, to help [others]. That's what I think Religion [RE] should be.

A more favourable comment comes from Mr Mark, who found that even with the present curriculum, there is scope for combining a knowledge-based with a life-centred approach.

Mr Mark: I don't think it is bad, I don't think it is bad. Because you have the first... I like the way you first have a story. Let's say, I covered San Martin this week. It opened on San Martin, then what San Martin did and you develop a lesson about San Martin. And then on how what San Martin did we can do in our own life. And practical things - to have mercy, how to help, to forgive. These things. 
However, for other State school teachers, the curriculum appears to be weak even on values and ethics. The Patri Said school teachers found that it was cognitively challenging and a less than relevant approach for their pupils.

MD: How do you feel about the syllabus? Are you happy with it?

MS ATTARD: No. No, not really. As I was saying, I think there's too much content in it. And the book doesn't talk at all - or a little, it only talks a little - about values, which children should be encouraged to practice, ethics which could help them further on in their lives... you have to do all that. It depends on the teacher. If the teacher wants to follow the book only, there's nothing prohibiting her, you know, you can just go through the book and it's enough for the exams.

Asked whether she supplements this textbook with other material or discussion on ethics and values, Ms Attard points out that for her, they were 'the most important' part of RE. Disconcertingly, the knowledge and outcome-based curriculum with its examination orientation was too similar to theology [for adults].

Ms Attard: Yes, I do something about ethics and values because I think that's the most important part of Religious Education. It's like theology, what they are presented with is theology. Even the exams are very difficult, they are very tricky. Very tricky.

Ms Tanti, also of Patri Said, talks about the difficulty she had with her lowerachieving Year 6 class and the level of abstraction of the 'cognitive' elements of the curriculum. More than this, the outcome-based curriculum led to two unintended negative consequences. The first was that pupils 'hated' RE; the second, that they forget or 'deleted' it as soon as they sat their examination.

Ms Tanti: They [the textbooks] are good for the exams. Because the children are [geared] for the exams. As soon as they sit the exams they 'delete'. They wipe out everything from their memory. That is the shame, because religion is to be lived. What we do with our lives. It should be something more. Even the resources we are given. For example, they could give us, what can I say? They could give us, for example, recorded stories, drama, and we can discuss them. These are the things that children will remember. But doing this is useless. Because the problem is this. No matter what you do, you are always restricted by the syllabus. I have a half hour [a day]. I have to teach what is required for the examination, because if I don't keep up, I will fall behind.

All four State school teachers felt that the syllabus was too vast and left little time for discussion of more ethical issues. 


\section{In a Catholic Church school}

An even more critical account of the RE curriculum was articulated by the RE teacher of St Anne's Church School, which had over the last year ${ }^{6}$ introduced its own syllabus and curricular materials. Whilst broadly working within the parameters of the national RE curriculum, the far more life-centred approach served as an example of what gains and losses could be expected from a move in this direction. As a trained teacher and member of St Anne's Religious Order, Sister Angela was better prepared theologically than lay teachers of Catholic RE.

Sr. Angela: The books are out of date, in my opinion. And something that is out of date you do not give to children. And this is then part of the curriculum. And when you begin to see we are updating, in every subject, what about Religion? Plus there are topics that for Year 5 are not that applicable to children.

According to Sr. Angela, it was not only that stories such as of the deaths of Ezekiel and Adam that 'don't make sense' to children, but the curriculum structure which partitioned topics over the primary school years was also without pedagogical principle.

Sr. Angela: And even how it is divided, that in one year you do Jesus, in another you do the Church, in another year you do... I prefer... This is what I think and what we have tried to do. I prefer it that every year you do a little of everything, do you understand? And you continue to build up. In one year you cannot do everything. But, as you go along, if you start from Year 1, you build up, and we are doing a bit on the Sacraments. [We do] what counts most in this particular year, and you build across the years. Ultimately it is going to make more sense to the children, and they feel part of it.

The enthusiastic Sr. Angela describes the school's curriculum plan and its objectives. From Year 3, children work on the following themes: the Old Testament, the New Testament; the Catholic Church; Morality and Prayer. The pedagogy blends the doctrinal and traditional with the experiential and interpretive. It is interactive, involving modern technology, outdoor activity, games, songs and others. Tellingly, traditional elements, such as learning prayers by rote, fall under the topic 'Catholic Church'.

Sr. Angela: What we did was we divided into five sections. We took Old Testament, New Testament, and then you have Catholic Church - because you have certain things that they have to learn. And then again, how to present these? And here is where Prayer comes in. The Sacraments - there 
is Morality, where values enter, I mean that is an area itself. Then we have Prayer. We are going to try, we are. Prayer not as in rote learning because that is under Catholic Church. During Prayer they are to be living the experience of prayer. Sometimes we will be going out, on a nature walk, and we will meet Jesus... this all used to be missing [from previous curriculum].

There is a close examination of the key religious text; one that was designed with the activities typical of this approach integrated into the body of the text. Sr. Angela describes how she uses group work to model the values of teamwork and to connect topics across themes, which link up to other religious activities carried out at the school level. This involves close collaboration with the class teachers and with the school administration.

Sr. Angela: Group work yes, also. For example, I don't know. If they are going to make a chart on what we did, if we did 'The first community', the first Christian community, Celebrating the Church's birthday, Pentecost. Then to understand that there was the first community, and how we [Christians] continued to grow. So they had [an introduction] into what the first elements were, how those who were Christian were distinguished from those who were not.

As with the interpretive approach, the children were repeatedly invited to connect the learning to their lives. Activities to support this linking were iterative and community building; they stretched over weeks, over classes, to the whole school.

Sr. Angela: And we extracted the most important elements, that they share everything. They lived one heart and one soul. So they [the pupils] had to, in a group, sort of, break up into groups and discuss what they understand by this. How can we today do something practical? Yes. That if in a particular week they are working on Morality, then all the year groups are too and then the whole junior school can have assemblies and other activities related to this. 'Team effort'?

\section{In an Islamic faith school}

At MIS, the teachers have to teach Islamic Studies through the medium of Arabic, which is, for a number of the pupils, a second or third language. Ms Bushra carried around with her a large teddy-bear who 'only understands Arabic' to encourage children to communicate in Arabic. Another teacher, Ms Jamila, outlines how the curriculum is spread over the primary school years. 
Ms Jamila ${ }^{8}$ : We get it [the syllabus] ready planned, it will be divided according to how we should work over the year, and that. Because even in Islam, when we enter a place [x'imkien] we say 'Salaam ghalikom'. It means the religion has Arabic as well. The Arabic [language] lesson, now in Year 1 and Year 2, the first lesson of Arabic, I teach them how to say 'Salaam ghalikom'. When they meet their friends and that, they have to say it.

A major objective is the inculcation of Islamic values and the Islamic way of life.

Ms Jamila: I teach values by talking to them and by praying here. And then we do not have the Qu'ran to teach, not only the Qu'ran. Because in our faith, we have prayer, we have history, Islamic history. I mean about six subjects in Islamic Education. They are not all Islam. And we explain the Qu'ran. How to apply what they have learnt in their lives.

Ms Jamila describes her method, how she moves from the transmitted tradition of the Qu'ran to the textbook, to discussion and finally to a more lifecentred approach, asking the children to take on the faith as their own.

Ms Jamila: Today we had a lesson in faith. How to believe. What it means to have really strong faith. You have to believe this and this and that and that. I have the book and I have the stories. We have the words of the Prophet Mohammed. I use these in the lesson to help the children learn. We've already completed this lesson, but there are sections that I need to read to the children. This time instead of reading myself [they will]. It means we have arrived at the last lesson. And then there are questions that they have to work on.

Within this curriculum, there are opportunities for some experiential learning but this too is circumscribed by the limits of the doctrinal approach.

Ms Jamila: We don't use it [group work] much here. But I often take them down to the Mosque where we have prayer and we have the lesson there. And I tend to their questions. I respect whoever wants to raise a question. I explain. Whoever wants to understand something, I explain to him or her. It's like a 'free lesson', talk, just talk. Not a lesson where we have studied this and this and that. Let us go to the holy place. Show all our respect and speak about religion in a proper way. I take them once or twice a year, not often. For them to have free talking, I mean. And we often have cassettes and they listen to them.

Reviewing a lesson I had just observed, Ms Jamila talks about how she introduced the Holy Books, the prophets (including Jesus) and the Prophet Mohammed as the messenger 'rasul', the last Prophet. She had spent time 
asking children how they could be good Muslims, which led to a discussion on care of the world Alla ${ }^{9}$ created. The children wanted to know more about the world, but she thought they were leading her too far into 'Geography'. She had drawn mountains and rivers on the board. She then goes on to emphasise that God had created everyone, irrespective of 'colour', such that at the end of the world 'we will be accepted into heaven not on the basis of colour' ${ }^{\text {'10 }}$ but on the merits of the life that has been lived. From their response, the children appeared to be actively engaged in examining this teaching through their own interpretation of what 'care for the world created by Alla' should look like. Ms Jamila was more than content with the way her pupils responded.

\section{Conclusion}

In this chapter the internal limitations of a denominational $\mathrm{RE}$ have been explored through looking at how teachers make sense of both more knowledgecentred as well as life-centred approaches. In the case of the centrally authorised knowledge-centred and outcomes-based approach of Catholic RE most evident in Maltese State schools, teachers feel severely limited in what can be achieved, and desire to engage in more spiritual or interpretive work.

Catholic RE teachers' accounts of their pedagogy indicate that for most teachers, a life-centred approach is essential for engaging children's interest in the more doctrinal or knowledge-based curriculum. Strategies to deal with the doctrinal element include storytelling, where children are transported to a state of wonderment through the narrative. Many of these stories about the prophets or the saints allow children to place themselves in a chain of memory (HervieuLéger, 2006). Pedagogical strategies also include using media such as DVD films, as well as other visual material.

In both the more knowledge-centred and life-centred approaches, what teachers and pupils do with the curriculum, translates the formal curriculum into something other than what curriculum planners intended. Teachers supplement the formal curriculum such that they indicate a desire to combine both knowledge and life-centred approaches in one coherent programme. St Anne's Church School worked intensively on a new approach. This curriculum was coherent with its objectives, which was to adopt a more interpretive life-centred approach that was, however, firmly anchored in a knowledge base. With more consistency with the ethos of the school, both the teacher and the pupils were ready to invest more into the project of RE. A Muslim faith school with a knowledge-centred approach also integrates a more hermeneutical element such that the children become eloquent 'messengers' or witnesses to the faith values themselves. In the revision of the Catholic RE curriculum that was taking place at the time, neither a 'world religions' intercultural, nor an interpretive 'edification' RE (Vermeer, 2010) was on the agenda. Since then, there have been revisions to the Catholic RE official curriculum (not discussed here); however, this chapter shows that how a RE curriculum is planned, what is taught and 
how it is taught should be problematised. It appears that teachers of both Catholic RE and Islamic Studies wish to combine interpretive and life-centred elements with knowledge-based foundations of their respective curricula.

\section{Notes}

1 This FP-7 study was co-funded by the European Commission and the University of Malta. Religious education in a multicultural society: School and home in comparative context. [REMC] Topic SSH- 2007-3.3.1 Cultural interactions and multiculturalisms in European societies. With partners from Ireland, Scotland, Germany, Belgium and Malta.

2 Though the one Islamic Faith school studied did receive some State funding.

3 Parliamentary Question 11995 of 2009.

4 This comment appears exactly here as it is in the original document, indicating that the document itself was written without due consideration to the rights of citizens and others in the pluri-cultural society Malta was fast becoming.

5 Fieldwork commenced in September 2008 and ended in April 2009.

6 From 2007.

7 This was the inspirational theme the school had chosen to work on that term.

8 Schools have been given a pseudonym that reflects the names the schools have. The Muslim faith school is one of only two in Malta. It was agreed that the school would be 'attributable' since a pseudonym would not provide confidentiality. However, with the exception of the school principal, whose interview is attributable, all teachers, parents and children have been given pseudonyms. 'Ms Jamila' is a pseudonym. Transliteration from the Maltese (or Arabic) into English is the author's own.

9 As pronounced in Maltese.

10 In the original Maltese 'il-kulur taghna'.

\section{References}

Borg, C. \& P. Mayo, (2001). 'Social difference, cultural arbitrary and identity: an analysis of a National Curriculum document in a non-secular environment', International Studies in Sociology of Education, 11:1, pp. 63-84.

Buchanan, M. J. \& K. Engebretson, (2009). 'The significance of theory in the implementation of curriculum change in religious education', British Journal of Religious Education, 31:2, pp. 141-152.

Debono, J., (2019). 'Growth in pupils choosing ethics over religious studies', in MaltaTodaywww.maltatoday.com.mt/news/national/92553/growth_in_pupils_choosing ethics_over_religious_studies\#.X3GoC2gzbIU, 31 January 2019.

Dillen, A., (2007a). 'Theologizing with children: a new paradigm for Catholic religious education in Belgium', in G. R. Grace \& J. O'Keefe (eds), International Handbook of Catholic Education: Challenges for School Systems in the 21st Century, Part One. Dordrecht, Springer, pp. 347-365.

Dillen, A., (2007b). 'Religious participation of children as active subjects: towards a hermeneutical-communicative model of religious education in families with young children', International Journal of Children's Spirituality, 12:1, pp. 37-49.

Eurydice, (2004). Integrating Immigrant Children into Schools in Europe: Malta: National Description, www.eurydice.org/Documents/Mig/en/frameset_immigrant.htm 1, last accessed February 2021. 
Grace, G., (2003). 'Educational studies and faith-based schooling: moving from prejudice to evidence-based argument', British Journal of Educational Studies, 51:2, pp. 149-167.

Grace, G., (2004). 'Making connections for future directions: taking religion seriously in the sociology of education', International Studies in Sociology of Education, 14:1, pp. 47-56.

Grace, G., (2009). 'On the international study of Catholic education: why we need more systematic scholarship and research', International Studies in Catholic Education, 1:1, pp. 6-14.

Grace, G., (2020). 'Taking religions seriously in the sociology of education: going beyond the secular paradigm', British Journal of Sociology of Education, 41:6, pp. 859-869.

Grace, G. \& R. Valenti, (2009). 'International Studies in Catholic Education (ISCE): preface and mission statement for the first issue', International Studies in Catholic Education, 1:1, pp. 1-4.

Halsall, A. \& B. Roebben, (2008). Religious Education in a Multicultural Society. Literature Review: International and Comparative Perspectives, Working Draft. www.esri.ie/ research/research_areas/education/Remc/working_papers/REMC_Literature_review.pdf, last accessed 8 November 2016.

Halstead, J. M., (1995). 'Should schools reinforce children's religious identities?', Religious Education, 90:3/4, pp. 360-376.

Hervieu-Léger, D., (2006). Religion as Chain of Memory. Cambridge: Polity Press.

Jackson, R., (2002). Religious Education: An Interpretive Approach, London: Hodder and Stoughton.

Jackson, R., (2004). 'Intercultural education and recent European pedagogies of religious education', Intercultural Education, 15:1, pp. 3-14.

MacMullen, I., (2004). 'Education for autonomy: the role for religious elementary schools', Journal of Philosophy of Education, 38:4, pp. 601-615.

Mawhinney, A., (2007). 'Freedom of religion in the Irish primary school system: a failure to protect human rights?', Legal Studies, 27:3, pp. 379-403.

Ministry of Education, (1999). Creating the Future Together: National Minimum Curriculum, Floriana: Ministry of Education. https:/education.gov.mt/en/resources/ Documents/Policy\%20Documents/national\%20minnimun\%20curriculum_english.pdf.

Secretariat for Catechesis, (2008). Religious Education in Malta: Reflections of the Catholic Community, unpublished mimeo, Secretariat for Catechesis, Archdiocese of Malta, pp. 1-42. http://gozodiocese.org/wp-content/uploads/2008/06/religious_educa tion_in_malta.pdf.

Smyth, E., Lyons, M., \& M. Darmody, (eds), (2013). Religious Education in a Multicultural Europe. Basingstoke: Palgrave Macmillan.

Vella, J., (1992). Compulsory Religious Education in the Primary School: A Conflict between Teachers' Rights/Professional Ethics and the Demands of a Mono-cultural Society?, unpublished B. Ed (Hons) dissertation, University of Malta.

Vermeer, P., (2010). Religious education and socialisation, Religious Education, 105:1, pp. 103-116.

Zammit Mangion, J., (1992). Education in Malta. Valletta: Studia Editions. 